\title{
Implementation Probem Based Learning Model to Enhance Ctirical Thinking IPA
}

\section{Sulastri, Anesa Surya}

SDN 2 Tegalsari, Universitas Sebelas Maret

\section{Article History \\ accepted 01/11/2020}

approved 08/11/2020 published 15/11/2020

\begin{abstract}
The objective of this research are improve critical thinking IPA by applying the Problem Based Learning (PBL) model. This research in Classroom Action Research with three cycles. The subject of this research were students of $V$ class at SDN 2 Tegalsari, totalling 35 students. The research uses data collection techniques test and nontes. Result of thorough were in the intitial conditions of critcal thinking skills $V$ class students showed $43 \%$ clasically. The first cycle resulting in a percentage of $40 \%$ in classial. The second cycle bresulting in a percentage of $86 \%$ in classical. The study continued with third cycle with the percentage of achivement at the first learning amounting 97\%.
\end{abstract}

Keywords: Problem Based Learning, Critical Thinking Skills

\begin{abstract}
Abstrak
Tujuan dalam penlitian ini adalah menerapkan model pembelajaran Problem Based Learning (PBL) untuk meningkatkan keterampilan berpikir kritis IPA. Penelitian ini merupakan penelitian tindakan kelas dengan tiga siklus. Subjek penelitian ini yaitu peserta didik kelas V SDN 2 Tegalsari berjumlah 35 peserta didik. Teknik pengumpulan data menggunakan tes dan non tes. Hasil penelitian sebelum tindakan terdapat $43 \%$ peserta didik yang tuntas secara klasikal. Siklus I sejumlah $40 \%$ peserta didik tuntas. Siklus II sejumlah $86 \%$ peserta didik tuntas. Penelitian dilanjutkan dengan siklus III yakni menghasilkan $97 \%$ peserta didik tuntas secara klasikal
\end{abstract}

Kata kunci: Problem Based Learning, Kemampuan Berpikir Kritis

Social, Humanities, and Education Studies (SHEs): Conference Series https://jurnal.uns.ac.id/shes

p-ISSN 2620-9284

e-ISSN 2620-9292 


\section{PENDAHULUAN}

Pembelajaran abad 21 merupakan pendidikan yang mengintegrasikan antara kecakapan pengetahuan, ketrampilan dan sikap serta penguasaan terhadap teknologi informasi dan komunikasi (TIK). Kecakapan yang dibutuhkan dalam dunia pendidikan abad 21 tersebut dapat dikembangkan melalui 4 C yaitu berpikir kritis (critical thinking), kecakapan berkomunikasi, (communication skills), kreatifitas dan inovasi (creativity and innovation) dan kecakapan kolaborasi (collaboration).

Namun kecakapan abad 21 tersebut masih perlu ditingkatkan khususnya pada pembelajaran IPA kelas V SD Negeri 2 Tegalsari. Hal ini terlihat dari peserta didik yang belum dapat mendeteksi permasalahan, tidak terdorong untuk melakukan pembuktian faktual, belum mampu membuat interpretasi pengertian, definisi dan isu kontroversi, serta belum mampu menarik kesimpulan dari data yang telah ada dan terseleksi.

Dampak yang akan terjadi jika hal tersebut tidak diatasi adalah peserta didik tidak dapat memunculkan ide-ide atau pemikiran baru mengenai permasalahan tentang dunia. Siswa tidak dapat menyeleksi berbagai pendapat yang relevan dan tidak relevan, pendapat yang benar dan tidak benar. Peserta didik juga tidak dapat menarik kesimpulan dengan mempertimbangkan data dan fakta yang terjadi di lapangan.

Tindakan yang akan diambil melalui problem based learning adalah memberikan orientasi masalah kepada siswa, mengorganisasikan siswa untuk belajar, membimbing siswa untuk mendapatkan pengalaman individu maupun kelompok, membimbing siswa mengembangkan dan menyajikan hasil karya dan menganalisis serta mengevaluasi proses pemecahan masalah bersama siswa.

Huda (2013: 271) mengemukakan bahwa pembelajaran berbasis masalah (Problem Based Learning) adalah pembelajaran yang memusatkan pembelajaran pada siswa. Pembelajaran berbasis masalah merupakan sebuah pendekatan pembelajaran yang menyajikan masalah kontekstual sehingga merangsang peserta didik untuk belajar (Kemendikbud, 2013). Pembelajaran berbasis masalah menurut Rusman (2014: 230) merupakan pembelajaran yang berkaitan dengan penggunaan intelegensi dari individu yang berada pada suatu lingkungan untuk memecahkan masalah yang bermakna dan kontekstual.

Penerapan model pembelajaran berbasis masalah terdiri atas lima langkah utama yang dimulai dengan guru memperkenalkan siswa pada situasi masalah dan diakhiri dengan penyajian dan analisis hasil kerja siswa. Langkah-langkah pembelajaran Problem Based Learning (PBL) sebagai berikut: orientasi siswa pada masalah, mengorganisasi siswa untuk belajar, membimbing pengalaman individual atau kelompok, mengembangkan dan menyajikan hasil karya, serta menganalisis dan mengevaluasi proses pemecahan masalah.

Menurut Sardiman (1996: 45), berpikir merupakan aktivitas mental untuk dapat merumuskan pengertian, mensintesis, dan menarik kesimpulan. Ngalim Purwanto (2007: 43) berpendapat bahwa berpikir adalah satu keaktifan pribadi manusia yang mengakibatkan penemuan terarah kepada suatu tujuan. Manusia berpikir untuk menemukan pemahaman/pengertian yang dikehendakinya. Santrock (2011: 357) juga mengemukakan pendapatnya bahwa berpikir adalah memanipulasi atau mengelola dan mentransformasi informasi dalam memori. Berpikir sering dilakukan untuk membentuk konsep, bernalar dan bepikir secara kritis, membuat keputusan, berpikir kreatif, dan memecahkan masalah.

Penelitian yang dilakukan Febriyanti Gita (2015) dengan judul penerapan model pembelajaran problem based learning untuk meningkatkan kualitas pembelajaran IPA kelas IV SDN Tambakaji 05 Kota Semarang. Hasil penelitian menunjukkan bahwa penerapan pendekatan pembelajaran berbasis masalah (Problem Based Learning) dapat meningkatkan ketuntasan belajar menulis siswa yaitu $66,67 \%$ pada siklus I menjadi $78,75 \%$ pada siklus II dan $88,09 \%$ pada siklus III. Simpulan penelitian, 
peningkatan kemampuan penguasaan IPA melalui model pembelajaran Problem Based Learning siswa kelas IV SDN Tambakaji 05 ini mengalami peningkatan.

Penelitian lain juga dilakukan bambang purnomo (2015) dengan judul penerapan model pembelajaran problem based learning dengan media video untuk meningkatkan kualitas pembelajaran tema peduli kepada makhluk hidup muatan IPS. Hasil penelitian menunjukkan bahwa penerapan pendekatan pembelajaran berbasis masalah (Problem Based Learning) dapat meningkatkan ketuntasan belajar menulis siswa yaitu pada siklus I 64,52\% , meningkat pada siklus II menjadi 70,59\%, dan meningkat pada siklus III menjadi 82,35 Simpulan penelitia ini yaitu melalui penerapan model Problem Based Learning dan media video dapat meningkatkan kualitas pembelajaran IPS pada siswa kelas IV SDN Ngaliyan 03 Kota Semarang.

Berdasarkan ulasan di atas, tujuan penelitian ini yakni meningkatkan keterampilan berpikir kritis IPA melalui penerapan model Problem Based Learning (PBL). Melalui adanya penelitian mengenai peningkatan keterampilan berpikir kritis ini, maka penelitian dapat dijadikan sebagai sumber rujukan untuk mengembangkan model inovatif lain meningkatkan keterampilan berpikir kritis

\section{METODE}

Penelitian Tindakan Kelas (PTK) tiga siklus ialah metode penelitian ini. Subyek penelitian yakni peserta didik kelas V SD N 2 Tegalsari tahun pelajaran 2018/2019 jumlah 35 peserta didik yang terdiri atas 20 peserta didik laki-laki dan 15 peserta didik perempuan. Penelitian mengaplikasikan teknik pengumpulan data berupa tes dan non tes. Non tes meliputi dokumentasi dan catatan lapangan. Analisis data pada penelitian ini menggunakan analisis kuantitatif Arikunto. Pedoman klasfikasi penilaian keterampilan pemecahan masalah soal cerita bangun datar diadaptasi oleh ahli.

\begin{tabular}{|c|c|}
\hline Kriteria Ketuntasan & Kualifikasi \\
\hline$\geq 75$ & Tuntas \\
\hline$<75$ & Tidak Tuntas \\
\hline
\end{tabular}

Ketercapaian target terampil penelitian ini yakni peserta didik mendapatkan kalsifikasi tuntas. Peserta didik mendapatkan skor akhir minimal klasifikasi tuntas dikatakan telah memiliki keterampilan berpikir kritis. Sehingga, apabila dalam penelitian ini $80 \%$ dari kesemua peserta didik menunjukkan klasifikasi tuntas, maka pengaplikasian PBL mampu menaikkan keterampilan berpikir kritis.

\section{HASIL DAN PEMBAHASAN}

Hasil serta pembahasan penelitian terdiri empat penyajian mengenai perkembangan keterampilan berpikir kritis peserta didik. Empat penyajian data tersebut, yakni: pratindakan, siklus I, siklus II, serta siklus III.

Keterampilan Berpikir Kritis Pratindakan

Hasil penelitian sebelum mengaplikasikan Problem Based Learning (PBL) didapat data bahwa keterampilan berpikir kritis rendah. Penyajian data pratindakan pada Gambar 1: 


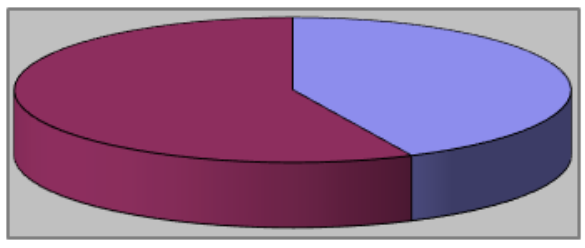

\section{$\square$ tuntas \\ $\square$ tidak tuntas}

Gambar 1. Hasil Keterampilan Berpikir Kritis Pratindakan

Gambar 1 menunjukkan hasil keterampilan berpikir kritis sebelum diterapkan PBL rendah. Presentase pesertadidik tuntas $43 \%$ sedangkan peserta didik tidak tuntas $57 \%$.

Keterampilan Pemecahan Masalah Soal Cerita Bangun Datar Siklus I

Hasil penelitian setelah menerapkan PBL didapat keterampilan berpikir kritis menunjukkan peningkatan. Penyajian data siklus I diperlihatkan Gambar 2 berikut.

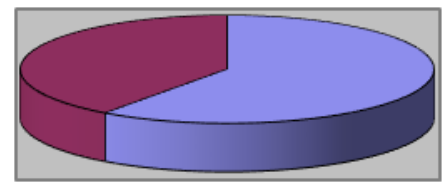

口Tuntas

口Tidak Tuntas

Gambar 2. Hasil Keterampilan Berpikir Kritis Siklus I

Gambar 2 menunjukkan hasil keterampilan berpikir kritis setelah diterapkan PBL pada siklus I. Presentase pesertadidik tuntas $40 \%$ sedangkan peserta didik tidak tuntas $60 \%$.

Keterampilan Pemecahan Masalah Soal Cerita Bangun Datar Siklus II

Hasil penelitian setelah menerapkan PBL didapat keterampilan berpikir kritis menunjukkan peningkatan. Penyajian data siklus I diperlihatkan Gambar 3 berikut. 


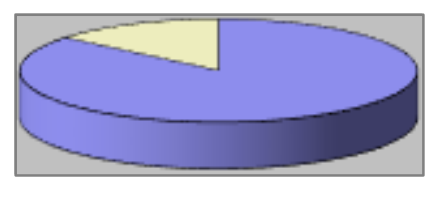

$\square$ Tuntas

$\square$ Tidak Tuntas

Gambar 3. Hasil Keterampilan Berpikir Kritis Siklus II

Gambar 3 menunjukkan hasil keterampilan berpikir kritis setelah diterapkan PBL pada siklus II. Presentase pesertadidik tuntas $86 \%$ sedangkan peserta didik tidak tuntas $14 \%$.

Keterampilan Pemecahan Masalah Soal Cerita Bangun Datar Siklus III

Hasil penelitian setelah menerapkan PBL didapat keterampilan berpikir kritis menunjukkan peningkatan. Penyajian data siklus I diperlihatkan Gambar 4 berikut

\section{Ketuntasan Belajar Siklus III}

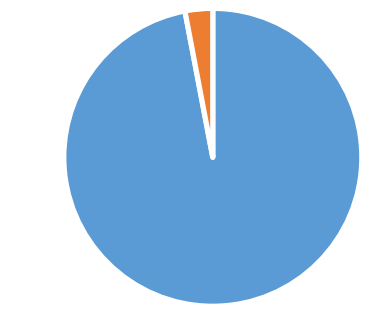

- Tuntas - Tidak Tuntas

Gambar 4. Hasil Keterampilan Berpikir Kritis Siklus III

Gambar 4 menunjukkan hasil keterampilan berpikir kritis setelah diterapkan PBL pada siklus III. Presentase pesertadidik tuntas $97 \%$ sedangkan peserta didik tidak tuntas $3 \%$.

Hasil penelitian dibuktikan melalui peningkatan hasil tes setelah dilaksanakan tindakan. Hasil tes sebelum tindakan menunjukkan terdapat $43 \%$ peserta didik memiliki keterampilan berpikir kritis. Kemudian permasalahan tersebut diatasi mengaplikasikan PBL sebagai solusi menaikkan keterampilan berpikir kritis. Setelah diberikan tindakan, hasil tes menunjukkan adanya peningkatakan presentase ketercapaian pada setiap pertemuan siklus I, siklus II, serta siklus III.

\section{SIMPULAN}

Berdasarkan hasil penelitian pada pembelajaran Tema Ekosistem dengan model PBL yang telah dilaksanakan di kelas V SDN 2 Tegalsari, maka peneliti menyimpulkan sebagai berikut: Penggunaan model Problem Based Learning dapat meningkatkan kemampuan berpikir kritis (C4) pada muatan pelajaran IPA dalam pembelajaran tema Ekosistem pada kelas V SDN 2 Tegalsari. Hal ini ditunjukkan dengan ketuntasan klasikal hasil belajar pada muatan pelajaran IPA pada siklus I sebesar $60 \%$, pada siklus II meningkat menjadi $86 \%$ meningkat sebesar $24 \%$ dan ketuntasan belajar siklus III adalah $97 \%$, meningkat 11\% dari siklus II. Berdasarkan 
hasil tersebut bisa disimpulkan bahwa indikator keberhasilan dalam penelitian ini tercapai.

\section{DAFTAR PUSTAKA}

Aqib Zainal. 2009. Penelitian Tindakan Kelas. Bandung : CV Yrama Widya.

Asrori, Mohammad. 2009. Penelitian Tindakan Kelas. Bandung: CV. Wacana Prima.

Gita, Febriyanti. 2015. Penerapan Model Pembelajaran Problem Based Learning Dengan Media Audiovisual Untuk Meningkatkan Kualitas Pembelajaran IPA Kelas IV SDN Tambakaji 05 Kota Semarang. Skripsi. UNNES

Purnomo, Bambang. 2015. Penerapan Model Pembelajaran Problem Based Learning Dengan Media Video Untuk Meningkatkan Kualitas Pembelajaran Tema Peduli Kepada Makhluk Hidup Muatan IPS. Skripsi. UNNES.

Sugiyono. 2010. Metode Penelitian Pendidikan, Pendekatan Kuantitatif, Kualitatif, dan $R \& D$. Bandung : Alfabeta

Trianto. 2011. Model -model pembelajaran Inovatif berorientasi kontruktivistik. Jakarta: Prestasi Pustaka.

Warsini. 2013. Penerapan Model Pembelajaran Problem Based Learning Dengan Media Film Dokumenter Untuk Meningkatkan Prestasi Dan Kesadaran Sejarah. UNS

Poerwanti, Endang, dkk. 2008. Asesmen Pembelajaran SD. Jakarta: Depdiknas. 